\title{
The Archbishopric of Manila Meets the Challenge of Shepherding Its Laity to Spiritual Maturity (1953-1963)
}

\author{
Melanie J. Magpantay ${ }^{1}$ and Antonio C. Hila² \\ ${ }^{1,2}$ The Graduate School, University of Santo Tomas, Manila, Philippines
}

\section{Article history:}

Submitted: 3 September 2020 Revised: 29 November 2020 Accepted: 31 December 2020

\section{Keywords: \\ Church history \\ Archbishops of Manila \\ Challenge and response \\ Historical Method \\ Philippines}

\begin{abstract}
This study discusses, narrates, and analyzes how Archbishop Rufino Santos continued the work started by the country's first native Archbishop of Manila, Gabriel M. Reyes, in steering the archbishopric to attain its full spiritual maturity. The research used the historical method guided by Arnold Toynbee's Challenge and Response Theory identifying the Archbishop of Manila as the "creative personality" whose responses to the challenges of the post-war Archdiocese of Manila formed a "creative minority" who helped him respond to the challenges during his stewardship. As the "creative personality," Archbishop Santos led a series of responses that began to stir the social awakening of the Catholic Church in the Philippines to make it responsive to the social issues affecting the Filipinos. These responses allowed Archbishop Santos to elevate the Catholic Action movement to include socio-political concerns, thereby awakening the laity's socio-political consciousness and linking this to their Filipino Catholic identity.
\end{abstract}

\subsection{Introduction}

The current use of Arnold Toynbee's Challenge and Response Theory in historical studies of the Philippines is to highlight the dynamic process of the encounter between social actors that brings changes in the social structures or how a society responds to the internal and external challenges and how these responses bring changes to society or an institution over time. Toynbee intended to use this theory on the macro level, such as the study of civilizations. However, it finds relevant use as a theoretical framework in the micro-level, that is, in the study of some institutions.

The Roman Catholic Archdiocese of Manila is one of those institutions where the Toynbeean theory may be applied at the micro-level as the current post-war historical account of the Archdiocese focused on the overview of the sociological development of its stakeholders (Yalung, 2000). There is a need for research that focuses on the leader of the Archdiocese of Manila and how he steered his flock towards spiritual reconstruction in the years prior to the opening of the Second Vatican Council.

\subsection{Methods}

The study used Arnold Toynbee's Challenge and Response Theory, but it centered on the role of the "creative personality," an individual that Toynbee defined as someone who strives to convert his fellow men into his insight, a genius who unintentionally creates a "disequilibrium produced by his creative energy" (Toynbee, 1972, p. 140). He has powers of attraction that enable a small group of other individuals to move towards his goal. This small group is what Toynbee calls the "creative minority" (Toynbee, 1972, p. 162-163). They are the persons who can move the uncreative people into the creative personality's vision so that society can cope successfully with the challenges. The growth or decline of the social structure results from the creative minority's ability to steer the social structure into their vision without using force by addressing external and internal challenges (Toynbee, 1972). These internal creative responses are a narrative on how the social structure's actions and reactions reflect the actions of the creative minority at the macro level.

The creative personality in this study is the second native Archbishop of Manila, Rufino Santos, whose stewardship of the Metropolitan See of Manila lasted two decades: 1953-1973. The research focuses on the first decade of Santos' stewardship, from the year of his assumption of the archbishopric in 1953 to 1963, the year when he was one of the Vatican Council II Fathers, and as a Cardinal, participated in the conclave for the election of Pope Paul VI. During these years, Archbishop Santos faced the challenges of reconstructing the war-ravaged physical structures of the Archdiocese and the dominating ideals of secularism and individualism that posed a spiritual threat to the laity of post-war Manila. The current study focuses on the latter by answering the question, "How did Archbishop Rufino Santos of Manila dynamically respond to the challenge of shepherding the laity into spiritual maturity during the first decade of his stewardship?" 
To address the study's main problem, the researcher used the historical method to describe, narrate, and analyze the very similar view of the past (Gottschalk, 1963; Lemon, 2003) guided by Toynbee's Challenge and Response theory in interpreting the facts gathered from primary and secondary sources.

\subsection{Results and Discussion}

The spiritual reconstruction of Archbishop Rufino Santos is anchored on his belief that the Catholic Church must make itself relevant to the lives of the Filipino people in their political, economic, cultural, educational, or spiritual life.

\section{On love of neighbor}

Archbishop Rufino Santos steered the Archdiocese into its full spiritual maturity by shepherding the laity towards socio-political involvement guided by his stewardship's central theme: love of God and love of neighbor. For the newly-installed Archbishop of Manila (1953b, p. 244), the Christian teaching founded on love unites everyone in principle and action to love one another as they love themselves. This is aptly expressed in the dictum, "Caritas in Dilectione," 'charity in love,' the motto in his coat-of-arms (Madriaga, 1953).

Guiding the Catholic Church in the Philippines to its full spiritual maturity means that the creative personality, the Archbishop of Manila, must steer the Metropolitan See into spurring the uncreative majority, the laity, into a creative effort towards the fulfillment of his goal. This, he did achieve first by laying out a "social program," he announced on the evening of his installation.

In a fraternal agape at the Winter Garden of Manila Hotel, in the presence of the Apostolic Nuncio and the Manila's elite, Archbishop Santos spoke of implementing a social welfare program whose focus is to gather funds to help the poor. He said that the poor are the main victims of misuse of resources and have become strangers to the Church, for they felt they were abandoned by God (Santos, 1953c, p. 280). He also said that the Church is concerned with the welfare of the poor. This concern for their welfare will urge the poor to perform their spiritual duties for God, however materially lacking they were.

The social welfare program called for asking for financial donations from the well-off members of society to support the material needs of the underprivileged. The Archdiocese was expected to initiate a donation of fifty to a hundred pesos a month. In contrast, the wealthy were expected to donate a peso a month. The collected funds will be used for "food, clothing, and medicines for distribution among our poor brethren, and the education of their children" ("Bishop Santos' Social Program Would Fight Communism with Works of Mercy," 1953). Archbishop Santos looked forward that in the long run, the program will be launched into a formal organization manned by capable persons ready for self-sacrifice, understanding, and has the will-power to make the project a successful one. He appealed again for support for this undertaking, the Church's response to the challenge of Communism ("Bishop Santos' Social Program Would Fight Communism with Works of Mercy," 1953).

In his response, Apostolic Nuncio Archbishop Egidio Vagnozzi (1953) said that "It is beautiful... and a great program" (p. 282), a pioneering step of the oldest Archdiocese of the country that speaks for the Catholic Church in the Philippines as a whole. With Archbishop Rufino Santos at the helm of the Metropolitan See, Archbishop Vagnozzi believed that "the Church with your appointment, is going to see a new era in the Philippines, an era in which the Church will become more and more a vital force in the life of this country..." (Vagnozzi, 1953, p. 283).

Archbishop Santos was a man ahead of his time who looked outward and persevered to make the Church an inclusive Church, a Church that counts on both the rich and poor alike, a Church "pervaded and ruled by charity" (Madriaga, 1953, p. 245).

By July 1953, or barely three months after his consecration as Archbishop, Rufino Santos announced the establishment of an archdiocesan department whose sole concern was on the welfare program for the indigents that he spoke about on the evening of his consecration as Archbishop. A department called "Catholic Charities" was created. It was an office directly under the supervision of the Archbishop and was tasked with the "distribution of food and clothing, giving employment to head of poor families and education for their children" ("Msgr. Santos Acts on Charity Projects," 1953, p. 2). It had a separate board of directors who governed six offices that were also its areas of concern: 
census and statistics, finance, procurement, distribution and medical care, educational and religious activities, employment and disposal ("Archbishop Santos Announces the Archdiocesan Department of 'Catholic Charities,' 1953, p. 488-489). The Archbishop planned to distribute relief and charity among indigents amounting to $\$ 500,000.00$ a year ("Editorial Catholic Charities, Inc.," 1953).

The postwar period saw the spread of the Catholic laity organizations from Manila to other dioceses throughout the country. Archbishop Gabriel M. Reyes institutionalized these lay organizations at the diocesan level, designating the Bishop or the Archbishop as the person who directs these organizations through the Archdiocesan Committee on Catholic Action. Following his predecessor's initiatives, Santos streamlined the social services that these lay organizations implemented in various degrees. This collectively resulted in what was known then as the Manila Catholic Charities, "a family welfare organization" (Mitchell, 1956, p. 570) that coordinated and intensified the social services "performed by the parishioners and parish groups under the direction of parish priests throughout the Archdiocese" (Mitchell, 1956, p. 570).

\section{The lay creative minority}

The Archbishop's actions slowly gained its momentum of spurring the "uncreative majority" into "creative action." Rufino Santos focused on the would-be teachers of the Catholic faith and doctrines. He would embark later on the untested waters of post-war political issues that affected the laity.

Archbishop Santos continued the project of Archbishop Gabriel M. Reyes when he led the opening of the Institute of Catechists on 4 July 1953. The institute that was housed in Sta. Isabel College intended to train catechists who will teach the Catholic faith and doctrine to elementary, high school, and college students. It had separate classes for men and women catechists who were taught every Saturday for 36 weeks. A catechist trainee had to be a "college student, a college graduate, a third or fourth year student" with proper recommendations from their parish priest and from other parish catechists ("Classes for Catechism Open July $4^{\text {th }}$," 1953). Trainees, who completed the mastery course, received an episcopal diploma and earned the eligibility to teach catechism to elementary and high school students in private or public schools. The catechetical training program was originally intended for the vicariates of Bulacan, Cavite, and Rizal provinces during the stewardship of Archbishop Gabriel M. Reyes in 1951. Two years after, Archbishop Santos as the president of the Catholic Welfare Organization, expanded the program to the whole Archdiocese of Manila. He called on the parish priests, school heads, Catholic Action members, Catholic teachers, and catechists to encourage enrollment ("Classes for Catechism Open July $4^{\text {th }}$ ", 1953).

The Archbishop then spoke to public school and non-sectarian teachers and reminded them that spreading Catholicism did not stop when they exited the Church, "If each Catholic were to spread his catholicity in his own sphere of influence, there would be no advancement on the part of the enemies of the Church" ("Msgr. Santos to Teachers "Spread Catholicity," 1953, p. 3). For the Archbishop of Manila, the duty of teaching encompassed not only the family but all those who came to the influence of teachers.

His focus on education was done. Archbishop Santos subtly moved to promote Catholic values in the media when he endorsed a Tagalog movie that portrayed the Church's stand on birth control, contraceptives, and abortion. May Karapatang Isilang (1953) is an adaptation of the Spanish film "Derecho de Nacer" that starred Filipino actors Jose Padilla, Rosa del Rosario, Rosita Noble, and Paraluman. Santos said that the Tagalog film "applies a very sound solution to the many problems of the day, which often pervade the homes" ("Archbishop Endorses Tagalog Movie," 1953, p. 10). The office of the Catholic Action of the Philippines took charge of selling the tickets to moviegoers.

This was the first of the many activities that the Catholic Action of the Philippines spearheaded during the stewardship of Archbishop Rufino Santos. Taking the lead from the ecclesiastical head of the Archdiocese of Manila, the Holy Name Society issued a manifesto abhorring the spread of pornographic literature especially reading materials that targeted young men and women ("Holy Namers War on Pornography," 1953).

The Holy Name Society was among the mandated organizations of Catholic Action Councils in all parishes in the Philippines. The other organizations were Legion of Mary, the Young Christian Workers, Students' Catholic Action, Sodality of Our Lady, Knights of Columbus, Catholic Women's League, Young Ladies Association of Charity, Conferencia de San Vicente de Paul, and the Catholic 
Youth Organization. By 1955, these organizations had a membership that reached 150,823 while there were 669 Catholic Action parish councils in the 28 dioceses of the Philippines ("Catholic Action Growing Annual Report Shows," p. 3).

The Parish Pastoral Councils also began collaborating with the Parish Welfare Committee in distributing clothing, material and providing medical aid to those in need. In 1956, the Parish Welfare Committees of Paco, San Miguel, "Pandacan, Binondo, San Jose de Trozo, Santísimo Rosario, Singalong, Malate, Ermita, San Vicente de Paul, San Roque, Peñafrancia, Espíritu Santo, and Assumption parishes" (Mitchell, 1956, p. 571) reported a regular service to about 25 families and 100 patients a week. This was the Councils' response to the call of Archbishop Santos to go to the poor ("Go to the Poor! Says Manila Archbishop," 1953).

By targeting the teachers of the faith and those who participate in the evangelizing mission of the Church, the Catholic Action organizations and the parish pastoral councils began moving on their own to promote Catholic faith and ideals.

The "creative personality" typified by the Archbishop now has formed his "creative minority," the laypeople and Catholic lay organizations that helped him in his advocacy.

\section{To Jesus through Mary}

Apart from rekindling the virtue of Caritas among the faithful, Archbishop Santos produced disequilibrium when he intensified the Marian devotion among the faithful of Manila by spearheading the celebration of the Marian Year in 1954. Manila's celebration was the Archdiocese response to the announcement of Pope Pius XII that 1954 was designated as Anno Mariano through the encyclical Fulgens Corona. The Marian Year celebrated the centennial of the definition of the Dogma of the Immaculate Conception.

As early as December 1953, Archbishop Santos set the ground moving for this celebration. He selected parishes dedicated to the Virgin Mary to be pilgrimage sites. The Santissimo Rosario parish of the University of Santo Tomas, the parish of Our Lady of Loreto in Sampaloc, the Virgen del Pilar church in the Sta. Cruz parish and Malate's Virgen de Los Remedios were the pilgrim sites in the City of Manila. The Nuestra Señora de Salambao in Obando was the Marian pilgrimage site for Bulacan. For Cavite, Archbishop Santos designated the pilgrims to the Nuestra Señora de la Soledad de Porta Vaga in Cavite City, while in Rizal, pilgrims could go to the Church of the Nuestra Señora de la Paz y Buen Viaje in Antipolo (Santos, 1953d).

Pilgrimage within the diocese was only the first of the many activities for the Marian Year. In a joint pastoral letter, the episcopate of the Philippines instructed all priests to stir up Marian devotion through "sermon lectures, novenae, pilgrimages, and other means that inspire their zeal" (Catholic Welfare Organization, 1954, p. 372) and during the exposition of the Blessed Sacrament, the recitation of the papal prayer for the Marian Year. They also expect that the lay will attend these Marian activities (Catholic Welfare Organization, 1954).

The most important of the announcement in the joint pastoral letter is the holding of the Second National Marian Congress in Manila on 1 to 5 December 1954.

In the midst of the preparations for the celebration of the Marian Year, Rufino Santos invoked another image of Mary, "Queen of Peace." The Archbishop spoke to the faithful on the radio on DZPI on the eve of the centennial of the Dogma of the Immaculate Conception on 7 December 1954. Santos cited the absence of charity and goodwill over the existence of contempt of the law that resulted in the absence of peace among humankind. To achieve peace was to turn to Mary, the Archbishop said, for the peace of the soul "must be deeply rooted on a spiritual order, that escapes the coldness of material ambitions" ("Turn to Mary Archbishop Urges," 1953, p. 2). For Archbishop Santos, the absence of peace of the soul resulted in national disintegration. The deterioration of peace led to hatred, and ultimately, brutality.

Archbishop Santos meant turning to Mary, Queen of Peace, to form the self and the familycentered on Marian's virtues. He reminded that the simple offering of flowers and prayers to the Blessed Mother was a manifestation of the submission of the self to God through Mary's intercession. He encouraged the faithful to place the Marian image in prominent places inside the homes and, most importantly, in the hearts of the faithful ("Turn to Mary Archbishop Urges," 1953).

The highlight of the celebration of Marian Year was observed on 8 December 1954, the centennial of the Dogma of the Immaculate Conception. Archbishop Santos allowed the celebration 
of a midnight mass on that day. He also reminded the parish priests not to break the 120-hour continuous Rosary in all parishes of the Archdiocese. The Archbishop also accompanied the Papal Legate to the Marian Congress, Archbishop Fernando Cardinal Quiroga of Santiago de Compostela, in laying the cornerstone of the eighth Manila Cathedral in Intramuros (Santos, 1954).

Capping the celebrations was a pontifical mass at the San Miguel Pro-Cathedral, a sacred concert that was broadcasted over the radio, and a Grand Rosary Rally at the Santo Domingo Church in Quezon City where Block Rosary Units of Manila and Quezon City participated (Santos, 1954).

The Marian Year festivities were not only in compliance with the call of the Supreme Pontiff but also ways to seek the Blessed Virgin's help for an increase in vocations. In his pastoral letter to the clergy and the faithful of the Archdiocese, Santos said that the Blessed Virgin's role as intercessor is an exercise of the ministry of mediation (Santos, 1955a).

Archbishop Santos also called for parents to make their families the moral, educational centers where Christian virtues were born and were fortified. These families should serve as sanctuaries of the genuinely Christian homes, where God is feared and loved, and his commands are faithfully fulfilled (Santos, 1955a, p. 44). Santos said that parents must encourage their children to pray the Holy Rosary in front of the image of the Blessed Virgin where the parents would narrate the Marian virtues so that the parents might exemplify how Mary raised Christ to be a man of character and love (Santos, 1955a, p. 47). This kind of family was what the Archbishop wanted to exist in the country that would become the source for drawing up religious vocations.

The Archbishop also ensured the participation of the Archdiocese to the centennial of the apparition of Our Lady in Lourdes, France. He organized an Archdiocesan Committee to oversee the activities of the Archdiocese for the said occasion. He instructed the holding of a novena or a triduum in honor of the Our Lady of Lourdes. On 11 February 1958, all parishes and chapels celebrated a special mass at noon, the time of the first apparition of the Lady at Lourdes. After the said date, all masses prayed the Centennial Prayer in Tagalog during the final prayers with the invocation, "Nuestra Señora de Lourdes, Rogad por Nosotros." The first Saturday of every month was dedicated in honor of the Virgin of Lourdes (Santos, 1958a, p. 84-85).

Archbishop Santos organized these Marian activities, for he deemed them necessary to affirm the Marian devotion of the Filipinos and renew the fruits of the Second Marian Congress of 1954. The Archbishop reminded the clergy and the faithful to constantly pray the Holy Rosary and pray it as a family. He also called for a campaign for Christian modesty in dressing and living. The Archbishop also called for the faithful to "make the purifying influence of the Immaculate Virgin Mary regenerate the customs and the way of living of our families and institutions" (Santos, 1958b, p. 162).

The Archbishop wanted Christian values to be imparted to schools to train the youth and keep Philippine traditional moral values because Western values did not conform to Christian values. He also appealed to intellectuals, teachers, doctors, and businessmen for them to be enlightened on the reality of God, emphasizing that disbelief in Him poses a danger to the salvation of the nation. For government leaders, the Archbishop appealed for a resurgence of honesty and sincerity (Santos, 1958b, p. 163).

The pattern of mobilizing the faithful for another Marian devotion in the Archdiocese of Manila re-emerged on September 1959 when Archbishop Santos instructed the vicars forane, parish priests, heads of Catholic educational institutions, leaders of Catholic Action movements and other religious organizations to prepare for a "Grand Family Rosary Rally" in Manila. Rev. Fr. Patrick Peyton, C.S.C. of the Family Rosary Crusade movement, guided how the event would be organized (Santos, 1959a, p. 468).

The Grand Family Rosary Rally was the stellar Marian event that the Archdiocese of Manila organized in the first ten years of Archbishop Santos' stewardship that designated a lay Catholic organization to be the organizer. The Archdiocese commissioned Ms. Joaquina Lucas and Ms. Paz Santos of the Legion of Mary to be the point persons of the Vicars Forane (Santos, 1959a). It was also the only Marian event that was organized without official prodding from the Holy See. The Archbishop emphasized the importance of the Rosary Rally in his pastoral letter stating the need for spiritual and moral recovery as there was an ongoing "catastrophic" "terrible breakdown of principles" brought about by modern and "pharisaical and superficial notions" (Santos, 1958c, p. 715).

The months of October and November 1959 were the designated months for the four grand Family Rosary rallies in Bulacan, Cavite, and Rizal that culminated in Manila. 
Archbishop Rufino Santos intensified the Marian devotion for a people already devoted to Mary as a response to two challenges that faced the Archdiocese: the need to increase vocations and the growing materialism and secularism of society. Archbishop Santos regarded these "modernistic" Western values as the reasons for the moral disintegration of the traditional Filipino society that centered on God and the unity of the family.

By rekindling the devotion to the Holy Rosary, Archbishop Santos mobilized the laity to assert Catholic ideals and culture. He believed that the Filipino families could become the bedrock of a Christian society formed on Christian moral values if they prayed the Rosary as a family. As the "creative personality" of the Archdiocese, Archbishop Rufino Santos organized activities for the growth of Marian devotion.

\section{The laity's socio-political consciousness and the Filipino Catholic identity}

The last spiritual reconstruction that Archbishop Santos led in his first ten-year stewardship of the Metropolitan See of Manila was awakening the laity's socio-political consciousness and linking this to their Catholic identity. Archbishop Santos moved the laity to advocate for the Church's cause, similar to his predecessor. The difference in his approach was that he shepherded the Church towards its full maturity by elevating the Catholic Action Movement to extend its concerns to socio-political issues concerning the Church, specifically religious instruction and elections.

Religious instruction in schools, especially in public schools, has been an advocacy of the Church since the stewardship of Archbishop Michael O'Doherty (served 1916-1949), who envisioned a group of laypersons who conducted catechism classes to pupils of public schools (Noone, 1989, p. 162-163). The amended 1935 Constitution preserved the provision of optional religious instruction in stateowned schools. Only pupils with parental consent to attend the religious education classes should be present during the catechism classes.

The step to eliminating the optional thirty-minute religious instruction in public schools was known with the leakage of the minutes of the annual meeting of the Philippine Masons. The official Catholic organ, The Sentinel, published a photostat copy of page 40 of the minutes of the January 1949 meeting that identified three top education officials who were Masons and were in charge of a special committee to eliminate religious instruction in public schools. The three Masons who sat as members of this special committee were identified as the Secretary of Education Cecilio Putong, Director of Public Schools Benito Pangilinan, and Assistant Director of Public Schools Venancio Trinidad ("Sentinel Exposes Education Bosses," 1953, p. 3). The Sentinel's exposé coincided when the Church Hierarchy was occupied with the First Plenary Council of the Philippines, and the Archdiocese of Manila was sede vacante, 24 January 1953.

Archbishop Santos was then Apostolic Administrator of the Archdiocese of Manila, the elected President of the Catholic Welfare Organization, and the Secretary-General of the First Plenary Council of the Philippines. He used the powers of these offices to lead the response to the challenge of the Masons' plan to eliminate religious instruction. First, Santos penned a joint pastoral letter addressed to the units of the Catholic Action of the Philippines congratulating the efforts of the lay organizations "in defense of the Constitutional rights of our citizens concerning optional religious instruction in public schools" (Santos, 1953a, p. 3). He assured the Catholic Action members of the Church Hierarchy's full support in their "sane and constructive efforts" (Santos, 1953a, p. 3) to uphold the rights of the parents of students who wish to avail of the optional religious instruction as provided by the amended 1935 Constitution, Article XIV, Section 5 (Official Gazette, n.d.).

Assured by the bishops' support, Catholic Action organizations wrote to President Elpidio Quirino (1948-1953) to ensure the right of parents who opted for religious instruction to their children. The letter requested an inquiry on the veracity of the said Masonic Committee for the Elimination of Religious Instruction. Malacañan received this letter but did not respond to it (Catholic Welfare Organization, 1953).

With the silent treatment from the Executive Department, Apostolic Administrator Rufino Santos then empowered the Catholic Welfare Organization Chairman of the Episcopal Commission on Education and Religious Instruction, Bishop Mariano Madriaga, D.D. of Lingayen, to write a letter to President Quirino protesting the proposed promotion of Benito Pangilinan as Undersecretary of the Department of Education (Catholic Welfare Organization, 1953, p. 157-158). For the Catholic Church, eliminating a constitutionally-given right for them and other religious groups to teach 
religious education in public schools meant that the government was not upholding the highest law of the land.

Quirino later pushed for Pangilinan's appointment as Undersecretary, a post that had been vacant for over a year ("Bishops Urge Action on Putong Controversy," 1953).

Unfazed by the disregard of the executive department, the National Catholic Action of the Philippines staged a rally at Luneta, later marched to Congress, and voiced out the Catholics' dissension on appointing a Mason who had deliberate means to undermine the constitutional provision for optional religious instruction. Students, members of the religious organization, and representatives from the provinces attended the rally led by Atty. Francisco Rodrigo, President of the National Catholic Action of the Philippines, Atty. Raul Manglapus, President of the Archdiocesan Committee of Catholic Action, and Mrs. Felicidad Silva of the women's representative to Catholic Action ("Mass Rally to Protest Pangilinan Appointment," 1953).

Victory for the Catholics came two years later when the Department of Education Secretary Gregorio Hernandez, Jr. issued Department Order no. 5, series 1955. Section 3 of the Department Order prescribed 30-minute staggered sessions, thrice a week before or after the official school schedule (Fifth Congress of the Republic, 1963, p. 418). Archbishop Santos (1955b) expressed his "heartfelt gratitude" for the decision of the government authorities who were "mindful of our people's welfare" (p. 420-421).

This incident showed Santos's adept handling of the situation that he positively responded to the challenge of providing catechetical instruction to students in public schools. This instance showed Rufino Santos as Apostolic Administrator, effectively wielding the power of the Catholic majority to defend Catholic ideals using democratic and peaceful means.

Archbishop Santos also wielded the power of the Catholic majority during the 1953 national elections that saw incumbent President Elipidio Quirino of the Liberal Party running against the Nacionalista standard-bearer Defense Secretary Ramon Magsaysay. A month before the November elections, he issued a call for the religious to vote ("Msgr Santos Urges Religious to Vote," 1953). He later reiterated this call to all of the faithful of the Archdiocese in a circular dated 15 October 1953. Archbishop Santos equated the individual vote as one that will "help mold the future of our country, either for better or for worse" ("Votes Mould Future of PI, Msgr Santos," 1953, p. 1). For the Archbishop, the duty of the human person during elections was to vote for leaders who would bring peace and freedom under Divine Providence. The power to vote showed the love of country rooted in the love of God and the Church ("Votes Mould Future of PI, Msgr Santos," 1953).

On the eve of the national elections, Archbishop Santos redefined the position of the Church on politics in a nationwide radio broadcast. As the Archbishop of the Metropolitan See of Manila and President of the Catholic Welfare Organization, Santos asserted that the Catholic Church treated politics "purely from the standpoint of morals and religion." ("Church's Position on Politics Defined by His Excellency, Msgr Santos," 1953, p. 2). The Church does this for the benefit of true religion: to ensure a just, equitable society with a strong family, a sense of civic responsibility, and obedience to authority. Archbishop Santos said that the Church "makes known her moral views on a political matter, she is but exercising a God-given right, a right fully protected by the Constitution" ("Church's Position on Politics," 1953, p. 11).

Archbishop Santos reiterated this stand in 1959 when he issued a circular cautioning the clergy, parish religious organizations, and religious organizations in educational institutions on aiding public movements that advocated political causes, specifically, "Filipinos for Democracy or FIDE." The Archbishop did not object to the individual members of the faithful to join the movement in their capacity as private citizens. He objects and warns the faithful so they may not be used as tools to bolster any political movement (Santos, 1959b, p. 652).

\section{Threading in uncharted waters}

The redefined stand of the Church on politics made her, in the words of Archbishop Santos, "Church persecuted" (Santos, 1956a, p. 352-353). The Archbishop's words came at the heat of his disagreement with then-Senator Claro M. Recto on the proposed required reading of the Noli Me Tangere and El Filibusterismo and other works of José Rizal as prescribed by Senate Bill 438 series of 1956. Recto was the principal author of this Senate bill that was later enacted into Republic Act no. 1425 and popularly referred to as "Rizal Law." 
The Church Hierarchy released a strongly worded statement that defended the right of the Church to oppose the new educational requirement. The Catholic Hierarchy of the Philippines asserted that the "novels contain teachings contrary to our faith and so, We are opposed to the proposed compulsory reading in their entirety of such books in any school in the Philippines where Catholic students may be affected" (Catholic Welfare Organization, 1956, p. 332). In place of the novels, the Church proposed preparing a Rizalian anthology that compiles all the social and political writings of Jose Rizal (Catholic Welfare Organization, 1956, p. 332-333).

Senator Recto's rebuttal was borne out of his silence prior to the Church's attack on Senate Bill no. 438 when he was branded by Catholic groups and candidates endorsed by the Catholic Church as anti-Christian and Communist. Recto dissected Archbishop Santos's open letter and argued that the "error in this statement is that it assumes that Rizal's teachings cannot be patriotic if they contain attacks against the Church. Which is untenable altogether" (Recto, 1990, p. 12). Recto pointed out how the Church made Senator Francisco Rodrigo as its spokesperson on the Senate floor, but when Rodrigo supported the amendments in the final version of the bill, the Church repudiated Senator Rodrigo when he "failed to live up to the Hierarchy's expectations, whatever they were" (Recto, 1990, p. 15). Recto also made it clear that the laws of the State were supreme over Canon Law, a fact the Archbishop received that as an attack to the Catholic Church, to the extent that Archbishop Santos adopted the catchphrase "persecuted Christianity" (Recto, 1990, p. 17).

Recto ended his letter cautioning Archbishop Santos on his statement that the Church did not slander the former in any way. The senator reminded the prelate how the Church used its media machinery-The Sentinel tabloid, the Kwentong Kutsero radio program, its holy hour nationwide radio broadcasts, and the numerous Catholic organizations-that vilified Recto's name during the senatorial campaign (Recto, 1990).

By the time Recto published his rebuttal, supporters of the Rizal Law had become vocal in their intent to prevent the display of clerical power in purely secular affairs. A new breed of anti-clericalism emerged, and the Catholic Welfare Organization rushed to put down the flames it created when it issued a pastoral letter anew, penned by Archbishop Rufino Santos on 5 May 1956.

The second pastoral statement on Rizal's novels reiterated the authority of the Bishop on upholding the Canon Law for Catholics that it was "a sin for any Catholic to read these novels in their entirety, or to keep, publish, sell, translate, or communicate the same to others in any form" (Santos, 1956b, p. 350). The Catholic Welfare Organization statement appealed for continued vigilance against those who attack the Church but was vague on its official stand on the novels, save for its title that indicates the pastoral stamp of approval: "OK'd."

The subtle recantation of its previous disapproval of the required reading of the novels showed that the Catholic Church, with the Metropolitan See of Manila as its lead, was not prepared on its redefined stance on politics. Archbishop Santos led the Church militant into warfare bearing the Church's colonial identity of meddling into purely secular matters in the guise of exercising a constitutionally-given right. This warfare adopted means contrary to Catholic teachings to achieve what the Church perceived as its divine duty: to assure the eternal salvation of souls. Recto pointed out this fact to Archbishop Santos, and no doubt, the senator stroke a chord to the Church Hierarchy's ego.

Archbishop Santos wielded the power of the Catholic majority to move the uncreative majority to act towards the response of the Church: eliminate the perceived threats to the Church's existence and its doctrine. He was successful in spurring the disequilibrium he wanted but was unprepared for the consequence of his intended action. The Archbishop of Manila was marred by the colonial identity of the Catholic Church-a defensive and intrusive Church—an identity that Santos sought to change but was limited by the ecclesiology of his time.

\subsection{Conclusion}

Archbishop Rufino Santos, as the creative personality, led the spiritual reconstruction of the Archdiocese in the first ten years of his stewardship with the vision of a Catholic Church in the Philippines that was more attuned to the social ills of its time, a vision he laid six years before Pope John XXIII (1959) called for an "aggiornamento," an updating of the church teachings and the opening of the Second Vatican Council.

As the "creative personality" of the Archdiocese, Rufino Santos moved the laity, his creative minority, into creatively responding to the challenges encountered by the Catholic Church in the 
Philippines. Santos produced a series of disequilibria that addressed the internal and external challenges of the Archdiocese of Manila. He was successful in inciting a response to Manila's Catholic laity, for they espoused the Archbishop's advocacies and followed his lead. They also spearheaded national Church events with the Church hierarchy assisting them as the ecclesiology of the period limited the governance and leadership of the Catholic Church to the ecclesiastical hierarchy only.

The Archbishopric of Manila, with its second native Archbishop, steered the Archdiocese into shepherding its laity towards its full spiritual maturity, making the faith timeless yet timely for its members. By the time Santos was elected into the College of Cardinals in 1960, he had brought the Archdiocese of Manila into the threshold of the Second Vatican Council.

\section{REFERENCES}

Archbishop Endorses Tagalog Movie. (1953, August 8). The Sentinel, p. 10.

Archbishop Santos Announces the Archdiocesan Department of "Catholic Charities." (1953, August) Boletín Eclesiástico de Filipinas 27(302), pp. 488-489.

Bishop Santos' Social Program Would Fight Communism with Works of Mercy. (1953, April 4). The Sentinel. p. 3.

Bishops Urge Action on Putong Controversy. (1953, February 21). The Sentinel. p. 3.

Castro, L. S. (1997). An Institutional History of Centro Escolar Señoritas, 1907-1941 [Unpublished master's thesis]. University of Santo Tomas, Manila.

Catholic Action Growing Annual Report Shows. (1955, January 15) The Sentinel, p. 3.

Catholic Welfare Organization. (1953, March). Joint Pastoral Letter of the Hierarchy on Religious Instruction in Public Schools. Boletín Eclesiástico 27(297), pp. 157-161.

Catholic Welfare Organization. (1954, June). Pastoral Colectiva del Episcopado Filipino sobre el Año Mariano. Boletín Eclesiástico de Filipinas 28(312), pp. 366-373.

Catholic Welfare Organization. (1956, May). Statement of the Philippine Hierarchy on the Novels of Dr. Jose Rizal Noli Me Tangere and El Filibusterismo. Boletín Eclesiástico de Filipinas 30(335), pp. 324-333.

Church's Position on Politics Defined by His Excellency, Msgr Santos. (1953, November 14). The Sentinel, p. 2 and 11.

Classes for Catechism Open July $4^{\text {th }}$. (1953, July 4). The Sentinel, p. 2.

Editorial Catholic Charities, Inc. (1953, July 25). The Sentinel, p. 4.

Fifth Congress of the Republic. (1963). Privilege Speech of Senator Padilla. In Republic of the Philippines Congressional Record: Senate, Volume 2, 415-421. Philippines: Bureau of Printing, https://books.google.com.ph/ books? id =cOpg17yoHTMC\&printsec $=$ frontcover $\# v=$ onepage $\& q \& f=$ false

Go to the Poor! Says Manila Archbishop. (1953, April 18). The Sentinel, p. 1.

Gottschalk, L. (1963). Understanding History, A Primer of Historical Method. Alfred A. Knopf.

Holy Namers War on Pornography. (1953, August 15). The Sentinel, p. 1.

John XXIII. (1959, January 25). ALLOCUZIONE DEL SANTO PADRE GIOVANNI XXIII CON LA QUALE ANNUNCIA IL SINODO ROMANO, IL CONCILIO ECUMENICO E L'AGGIORNAMENTO DEL CODICE DI DIRITTO CANONICO. La Santa Sede. http://www.vatican.va/ content/john-xxiii/it/speeches/1959/documents/hf_j-xxiii_spe_19590125_annuncio.html

Kerby, W. J. (1921). The Social Mission of Charity A study of points of view in Catholic Charities. The Macmillan Company. Lemon, M. C. (2003). Philosophy of History A Guide for Students. London: Routledge.

Madriaga, M. (1953, April). Coat-of-Arms of Archbishop Rufino Santos, D.D. Boletín Eclesiástico de Filipinas 27(298), pp. 244-246.

Mass Rally to Protest Pangilinan Appointment. (1953, February 14). The Sentinel, p. 3.

Mitchell, T. A. (1956), "Social Service in the Parish," Philippine Studies 4(4) 570-572, https://www.jstor.org/stable/42719256.

Msgr Santos Urges Religious to Vote. (1953, October 3). The Sentinel, p. 3.

Noone, M. J. (1989). The Cultural Conflict, The Life and Times of Michael O'Doherty Archbishop of Manila, in General History of the Philippines (Part V Vol. 3). Historical Conservation Society.

Official Gazette. (n.d.) 1935 Constitution Amended. https://www.officialgazette.gov.ph/constitutions/1935-constitution-ammended/

Recto, C. M. (1990). The Vision of A Prelate An Open Letter to the Archbishop of Manila. In I.R. Medina and M.S. Feliciano (annotated) The Complete works of Claro M. Recto Volume 9 (pp. 10-19). Claro M. Recto Memorial Foundation.

Santos, R. J. (1953a, February 14). Joint Pastoral Letter Bishops Back Fight for Religious Rights. The Sentinel, p. 3. . (1953b, April). Address of His Grace, Most Rev. Rufino J. Santos, D.D., Archbishop of Manila Delivered at the Metropolitan Pro-Cathedral, By His Grace in Response to the Greetings of Welcome of Rt. Rev. Jose N. Jovellanos, P.D., in the Name of the Clergy and Faithful of Manila. Boletín Eclesiástico de Filipinas 27(298), pp. 243-244.

(1953c, May). Address of His Grace, Most Rev. Rufino J. Santos, D.D., Archbishop of Manila at the Fraternal Agape Given at the Winter Garden of the Manila Hotel. Boletín Eclesiástico de Filipinas 27(299), pp. 278-283. . (1953d, December). Año Mariano Circular. Boletín Eclesiástico de Filipinas 27(306), pp. 749-750.

. (1954, December). Closing of the Marian Year in our Archdiocese. Boletín Eclesiástico de Filipinas 28(318) pp. 769-770. . (1955a, January). Carta Pastoral sobre Maria Inmaculada y las Vocaciones Sacerdotales. Boletín Eclesiástico de Filipinas 29(319), pp. 35-49.

(1955b, July). Statement on Adherence to Religion. Boletín Eclesiástico de Filipinas 29(325) pp. 420-421.

. (1956a, June). Circular Letter to All Our Very Reverend Parish Priests and Their Assistants, Catholic Action And Beloved

Faithful In General (On Church Persecuted May 5, 1956). Boletín Eclesiástico de Filipinas 30(336), pp. $352-353$.

. (1956b, June). CWO Statement on Rizal Novels OK'd By Hierarchy. Boletín Eclesiástico de Filipinas 30(336), pp 348-351.

. (1958a, February). Carta Circular Re: Primer Centenario de las Apariciones de la Virgen de Lourdes 24 de Enero de 1958.

Boletín Eclesiástico de Filipinas 32(356), pp. 84-85.

. (1958b, March). Carta Pastoral Sobre las Apariciones de la Virgen Inmaculada en Lourdes, Francia 1858-1958 11 Febrero de

1958. Boletin Eclesiastico de Filipinas 32(357), pp. 158-165.

(1959a, August). Preparation for the Grand Family Rosary Crusade. Boletín Eclesiástico de Filipinas 33(375), p. 468.

(1959b, November). Circular Letter Warning against Official Church Participation in Political Campaigns. Boletín Eclesiástico

de Filipinas 33 (378) p. 652. 
. (1959c, December). Pastoral Letter on the Family Rosary Crusade. Boletín Eclesiástico de Filipinas 33(379), pp. 715-717 Sentinel Exposes Education Bosses. (1953, January 24). The Sentinel, p. 3.

Toynbee, A. (1972) A Study of History. Oxford University Press.

Turn to Mary Archbishop Urges. (1953, December 12). The Sentinel, p. 2.

Vagnozzi, E. (May 1953). Archbishop of Manila at the Fraternal Agape Given at the Winter Garden of the Manila Hotel. Boletín Eclesiástico de Filipinas 27(298), pp. 282-283.

Votes Mould Future of PI, Msgr Santos. (1953, October 31). The Sentinel, p. 1 and 12.

Yalung, C. A. (ed). (2000). Archdiocese of Manila: a pilgrimage in time. Roman Catholic Archdiocese of Manila.

\section{Correspondence:}

MELANIE J. MAGPANTAY

melaniemagpantay@gmail.com

https://orcid.org/0000-0002-7240-0869

ANTONIO C. HILA

tonioan47@yahoo.com 